\title{
Immune Lysis of Normal Human and Paroxysmal Noc- turnal Hemoglobinuria (PNH) Red Blood Cells. I. The Sensitivity of PNH Red Cells to Lysis by Complement and Specific Antibody*
}

\author{
Wendell F. Rosse † And J. V. Dacie \\ (From the Department of Haematology, Postgraduate Medical School, London, England)
}

Ham and Dingle (1) demonstrated for the first time that the red cells of patients with paroxysmal nocturnal hemoglobinuria $(\mathrm{PNH})$ are unusually susceptible to lysis by hetero- and isoantibodies and complement. These observations have since been confirmed by many other studies using a variety of antibodies (2). The susceptibility of these cells to lysis by antibody and complement has been utilized in the detection of hemolytic antibodies in human serum (3) and in the analysis of the kinetics of hemolysis of human cells by specific antibody and complement (4).

The red cells of patients with $\mathrm{PNH}$ are also lysed by fresh normal serum, especially when the $\mathrm{pH}$ is reduced to 6.5 to $7.0(5,6)$. This reaction, the acidified serum test or Ham's test, is of major importance in the diagnosis of the disease. Lysis by acidified normal serum is abolished when the serum is treated with ammonia or heated to $56^{\circ} \mathrm{C}$ for 30 minutes $(1,7)$, procedures that destroy components of serum complement $\left(\mathrm{C}^{\prime}\right)$. This strongly suggests that serum complement is important in bringing about lysis by normal serum in this test and, by extension, in the vascular system during circulation of the cells. Therefore, we have studied in detail the lysis of normal and $\mathrm{PNH}$ red cells by complement and specific antibody.

To assess differences in the relative sensitivity of normal and PNH cells to lysis by antibody and

\footnotetext{
* Submitted for publication May 25, 1965; accepted January 20, 1966.

† Address requests for reprints to Dr. Wendell $F$. Rosse, Dept. of Medicine, Duke University Medical Center, Durham, N. C.

Work performed during tenure as a visiting research fellow from the Metabolism Service, National Cancer Institute, Bethesda, Md.

This work was presented in part at the $\mathrm{X}$ Congress of the International Society of Haematology, Stockholm, Sweden, August 29 to September 4, 1964.
}

$\mathrm{C}^{\prime}$, we have modified and adapted the standard quantitative technique of Mayer for the estimation of serum complement $(8 a)$. In our tests, a fixed number of the human red cells to be tested were sensitized with a fixed excess of antibody; they were then treated with graded amounts of fresh normal serum containing a known amount of $C^{\prime}$. The amount of lysis was measured, and the amount of $C^{\prime}$ needed to lyse half the cells was used as an index of the relative sensitivity of the cells to complement lysis.

These studies show that the red cells of patients with $\mathrm{PNH}$ consist of two populations : one population is markedly sensitive to complement lysis, requiring about one-twenty-fifth the amount of $\mathrm{C}^{\prime}$ for $50 \%$ lysis compared with normal cells; the other population is usually slightly more sensitive to complement than normal cells, although exceptionally the sensitivity may be normal. The proportion of sensitive cells in the blood varies from patient to patient. This increased sensitivity appears to be fundamental to the hemolysis of $\mathrm{PNH}$ cells in vivo during circulation and in vitro by acidified serum.

\section{Methods}

Red cells. The cells from 11 patients with $\mathrm{PNH}$ were used. Short summaries of the clinical and hematological status of all 11 patients studied are included in Table I. The diagnosis of $\mathrm{PNH}$ in each case was made on the basis of history, clinical and laboratory examination, and a positive acidified serum lysis test (Ham's test), except as noted. Blood samples from these patients were removed aseptically by venesection, defibrinated, and immediately centrifuged in the cold. The serum was removed, and the cells were suspended in sterile Alsever's solution made according to Mayer's formula ( $8 b)$. The cells were stored at $4^{\circ} \mathrm{C}$. When preserved in this fashion, they maintained their initial characteristics for at least 6 weeks. Red cells from normal control subjects and from patients suffering from hematological diseases 
TABLE I

Clinical and laboratory data on patients with $P \mathrm{NH}^{*}$

\begin{tabular}{|c|c|c|c|c|c|c|c|c|c|}
\hline \multirow[b]{2}{*}{ Patient } & \multirow[b]{2}{*}{ Age } & \multirow[b]{2}{*}{ Sex } & \multirow[b]{2}{*}{$\begin{array}{l}\text { Hemo- } \\
\text { globin }\end{array}$} & \multirow[b]{2}{*}{$\begin{array}{l}\text { Reticulo- } \\
\text { cytes }\end{array}$} & \multirow{2}{*}{$\begin{array}{l}\text { Dura- } \\
\text { tion of } \\
\text { illness }\end{array}$} & \multicolumn{4}{|c|}{ Clinical condition } \\
\hline & & & & & & Presentation & Present state & $\begin{array}{l}\text { Transfusion } \\
\text { requirements }\end{array}$ & $\begin{array}{c}\text { Sple- } \\
\text { nectomy }\end{array}$ \\
\hline C.T. & $\begin{array}{c}\text { years } \\
21\end{array}$ & $\mathbf{M}$ & $\begin{array}{c}g / 100 \mathrm{ml} \\
4.0\end{array}$ & $\begin{array}{c}\% \\
16\end{array}$ & $\begin{array}{c}\text { years } \\
2 \frac{1}{2}\end{array}$ & Aplastic anemia & $\begin{array}{l}\text { Markedly decom- } \\
\text { pensated }\end{array}$ & Massive & Yes \\
\hline K.P. & 28 & $\mathbf{F}$ & 5.8 & 17 & 1 & $\begin{array}{c}\text { Hemolytic } \\
\text { anemia }\end{array}$ & $\begin{array}{l}\text { Decompensated } \\
\text { hemolytic anemia }\end{array}$ & Every month & No \\
\hline C.L. & 55 & F & 11.1 & 11 & $\frac{1}{2}$ & $\begin{array}{c}\text { Hemolytic } \\
\text { anemia }\end{array}$ & $\begin{array}{l}\text { Compensated } \\
\text { hemolytic anemia }\end{array}$ & None & No \\
\hline B.G. & 32 & F & 7.4 & 25 & 13 & Aplastic anemia & Decompensated & $\begin{array}{l}\text { Every } 4 \\
\text { months }\end{array}$ & Yes \\
\hline M.B. & 48 & $\mathrm{~F}$ & 10.9 & 2.8 & 14 & Aplastic anemia & Compensated & None & No \\
\hline H.H. & 42 & $\mathbf{F}$ & 5.2 & 8 & $\frac{3}{3}$ & $\begin{array}{c}\text { Hypoplastic } \\
\text { anemia, } \\
\text { hemolysis }\end{array}$ & $\begin{array}{l}\text { Deceased } \\
\quad \text { (marrow aplasia) }\end{array}$ & Massive & No \\
\hline J.S. & 60 & $\mathbf{M}$ & 7.6 & 13 & $1 \frac{1}{2}$ & $\begin{array}{l}\text { Hemolytic } \\
\text { anemia, } \\
\text { hemoglobinuria }\end{array}$ & $\begin{array}{l}\text { Compensated } \\
\text { hemolytic anemia }\end{array}$ & None & No \\
\hline S.M. & 34 & $\mathbf{F}$ & 11.5 & 1.0 & $6 \frac{1}{2}$ & Aplastic anemia & Clinically well & None & Yes \\
\hline K.H.D. & 52 & $\mathbf{M}$ & 3.9 & 2.7 & $\frac{1}{2}$ & Aplastic anemia & Severe anemia & Massive & No \\
\hline H.M. & 48 & $\mathbf{F}$ & 14.6 & 2.5 & 15 & Hemoglobinuria & Clinically well & None & No \\
\hline A.H. & 43 & $\mathbf{M}$ & 15.4 & 1.2 & 31 & $\begin{array}{l}\text { Aplastic anemia } \\
\text { (familial) }\end{array}$ & Well & None & Yes \\
\hline
\end{tabular}

* These data refer to observations made at the times of the complement lysis studies. PNH = paroxysmal nocturnal hemoglobinuria.

other than PNH were obtained and preserved in the same way.

Sterile sheep red blood cells 1 derived from defibrinated blood suspended in sterile Alsever's solution were used after storage for only 1 week. The cells were prepared for use by washing in barbital (Veronal)-saline buffer (VSB) (see below) three times. A suspension containing $10^{\circ}$ red cells per $\mathrm{ml}$ was made according to Mayer's method $(8 c)$. Human red cells were prepared for use by the same method. However, the standard suspension used contained $2 \times 10^{8}$ cells per $\mathrm{ml}$. This suspension was made by diluting $0.5 \mathrm{ml}$ of washed, packed cells in $18 \mathrm{ml}$ of VSB. The volume of this suspension was then adjusted so that a 1 in 25 dilution in $0.04 \% \mathrm{NH}_{4} \mathrm{OH}$ had an OD of 0.210 at a wavelength of $541 \mathrm{~m} \mu$, as measured in a Unicam spectrophotometer.

Red cells were papainized by mixing $0.25 \mathrm{ml}$ of washed, packed red cells suspended in VSB to a total volume of $1.8 \mathrm{ml}$ with $0.2 \mathrm{ml}$ of a $2 \%$ solution of papain. The mixture was incubated 20 minutes at $37^{\circ} \mathrm{C}$, and these cells were washed three times with VSB.

Antibodies. A cold-reactive antibody of anti-I specificity and very high hemolytic titer was obtained from a patient suffering from autoimmune hemolytic anemia of the cold agglutinin antibody type. The serum was preserved at $-60^{\circ} \mathrm{C}$ and was heated at $56^{\circ} \mathrm{C}$ for 30 minutes before use in order to destroy complement activity. This serum had very little anticomplementary ac-

1 Staynes Laboratories, High Wycombe, England. tivity when tested in the sheep red cell-rabbit antiserum hemolytic system.

Serum containing a typical Donath-Landsteiner antibody was obtained from a patient suffering from paroxysmal cold hemoglobinuria associated with congenital syphilis; this antibody was stored and prepared for use as outlined above.

Serum containing anti- $\mathrm{p}^{\mathrm{k}}$ as an isoantibody was stored and prepared for use as outlined. 2

Purified $\mathrm{O}$ antigen ${ }^{3}$ from Shigella shigae, prepared by the method of Davies, Morgan, and Mosimann (9), was treated with $\mathrm{N} / 50 \mathrm{NaOH}$ for 18 hours at $37^{\circ} \mathrm{C}$ and was attached to red cells by incubating $50 \mu \mathrm{g}$ in $2 \mathrm{ml}$ with 8 $\mathrm{ml}$ of a standard suspension of red cells (see above) at $37^{\circ} \mathrm{C}$ for 30 minutes.

An antiserum prepared in rabbits to whole sheep red cells was heated to $56^{\circ} \mathrm{C}$ for 30 minutes, diluted $1 / 100$, and stored at $-20^{\circ}$ C. 4

Human complement. Whole human serum was obtained from the blood of normal subjects by defibrination and centrifugation at $4^{\circ} \mathrm{C}$. During use, the serum was

2 Kindly provided by the Lister Institute, London, England.

3 This antigen and the rabbit macroglobulin antibody to it (partially purified by sucrose gradient ultracentrifugation) were kindly supplied by Dr. J. Humphrey of the National Institute for Medical Research, Mill Hill, England.

4 Obtained from Staynes Laboratories. 
kept at $0^{\circ} \mathrm{C}$ in a melting ice bath. This serum was stored in $1-$ to $2-\mathrm{ml}$ or $10-\mathrm{ml}$ volumes in sealed bottles at $-90^{\circ} \mathrm{C}$ in a dry ice chest. Once diluted, the unused serum was discarded. Only sera whose complement titer was between 34 and $42 \mathrm{C}^{\prime} \mathrm{H}_{50} \mathrm{U}$ as determined with sensitized sheep cells (8) were used. Lysis due to isoantibodies was prevented by using serum of the same ABO group as the cells being tested.

Guinea pig complement. Blood was obtained from young guinea pigs and allowed to clot at room temperature for 1 to 2 hours. The serum was removed and pooled. Naturally occurring antibodies to human or sheep red cells were removed by reacting 1 part of washed normal human or sheep red cells with 10 parts of serum at $0^{\circ} \mathrm{C}$ for 10 minutes. After removal of the cells by centrifugation at $0^{\circ} \mathrm{C}$, the guinea pig serum was stored in $1-$ to $2-\mathrm{ml}$ volumes in sealed bottles at $-90^{\circ} \mathrm{C}$.

Buffer. An isotonic VSB was used throughout the experiments unless otherwise stated. This buffer was made according to Mayer's formula (8b).

Complement titration. The complement titration of Mayer and co-workers (8a) using sheep cells and rabbit antiserum to sheep cells was used for the estimation of complement in human serum.

Optimal dilution of antibody. The following procedure was used to determine the amount of antibody which, in the presence of a fixed quantity of $\mathrm{C}^{\prime}$, will lyse the greatest number of red cells. Equal volumes of the standard suspension of cells to be tested and doubling dilutions of antibody were mixed at $0^{\circ} \mathrm{C}^{5}$ or room temperature (about $20^{\circ} \mathrm{C}$ ) for each dilution of antibody being tested. A set of three tubes was prepared: $1-\mathrm{ml}$ volumes of the mixtures of cells and antibody were pipetted into tubes labeled 1,2 , and 3 containing $5.5 \mathrm{ml}$ and $6.5 \mathrm{ml}$ of $\mathrm{VSB}$ (at $0^{\circ} \mathrm{C}$ ) and $6.5 \mathrm{ml}$ of $0.04 \% \mathrm{NH}_{4} \mathrm{OH}$, respectively. One $\mathrm{ml}$ of a dilution of normal human serum (diluted 1 part +4 parts VSB when normal cells were used or 1 part +14 parts VSB when $\mathrm{PNH}$ cells were used) was added to each of the tubes labeled 1. After mixing, the tubes were kept at $0^{\circ} \mathrm{C}$ for 12 minutes after which they were placed at $37^{\circ} \mathrm{C}$ for 1 hour. After centrifugation, the amount of hemolysis was determined from the optical density of the supernatant fluid at $541 \mathrm{~m} \mu$ in a Unicam spectrophotometer. The degree of hemolysis was determined after correcting for noncomplement lysis (tube 2) and complement color. The dilution of antibody giving the most lysis was ascertained.

Acidified serum lysis test. Lysis of $\mathrm{PNH}$ cells in acidified serum was measured as described by Dacie and Lewis (10). When large numbers of cells were required, tenfold increases in volumes were used.

Complement sensitivity test. To determine the relative sensitivity of red cells from various patients to $C^{\prime}$, we used the following test, based on the complement titration described by Mayer (8a). Cells sensitized with a constant excess of antibody (the dilution of the antibody

5 When antibodies that react at room temperature (anti-Shigella polysaccharide and iso-anti- $\mathrm{p}^{\mathrm{k}}$ ) were used for sensitization of the red cells, maintenance and incubation at $0^{\circ} \mathrm{C}$ were omitted. being used that lysed the greatest number of normal cells under conditions of limited $C^{\prime}$ ) (see above) were lysed by graded amounts of $\mathrm{C}^{\prime}$ in a given reaction volume at given reaction times and temperatures. To obtain graded amounts of $C^{\prime}$ without making separate dilutions for each tube, we added different volumes of a single basic dilution to each of six tubes containing sensitized cells and sufficient VSB to bring the final total volume to $7.5 \mathrm{ml}$. The basic dilution was selected to give partial lysis in all tubes insofar as possible. When normal cells were being tested, this dilution of serum was usually 1 in 3 to 1 in 5. Because of the wide range of sensitivity of the cells in the blood of all patients with $\mathrm{PNH}$, four groups of six tubes were used to analyze each sample of cells; the basic dilutions of $\mathrm{C}^{\prime}$ used for these groups were usually 1 in 100,1 in $33.3,1$ in 10 , and 1 in 3.33 , respectively.

For each basic dilution of $\mathrm{C}^{\prime}$ to be tested, $4.5 \mathrm{ml}$ of the standard suspension of cells in VSB was mixed at $0^{\circ} \mathrm{C}^{5}$ with $4.5 \mathrm{ml}$ of antibody in the dilution optimum for normal cells. One-ml portions were immediately pipetted, with mixing, into each of six tubes containing, respectively, 4.0, 3.5, 3.0, 2.5, 1.5, and $0.5 \mathrm{ml}$ of ice-cold buffer in an ice bath. In addition, $1.0 \mathrm{ml}$ was pipetted into 6.5 $\mathrm{ml}$ of VSB (cell control) and $1.0 \mathrm{ml}$ into $6.5 \mathrm{ml}$ of $0.04 \%$ $\mathrm{NH}_{4} \mathrm{OH}$ ( $100 \%$ lysis control). Sufficient complement in the dilution being tested was pipetted into each of the six tubes to adjust the final volume to $7.5 \mathrm{ml}$. The tubes were incubated for 12 minutes at $0^{\circ}$ and then for $60 \mathrm{~min}$ utes at $37^{\circ} \mathrm{C}$. After centrifugation, the optical density of the supernatant fluid at a wavelength of $541 \mathrm{~m} \mu$ was determined, and the color due to nonspecific lysis and to complement was subtracted by use of the appropriate controls. The fraction of cells lysed, $y$, was determined by dividing the corrected optical density by the optical density of the completely lysed sample corrected for nonspecific lysis. The logarithm of $y /(1-y)$ was plotted against the logarithm of the number of milliliters of complement used. For normal cells, the amount of $\mathrm{C}^{\prime}$ giving $50 \%$ lysis was determined from the intercept of the resultant straight line with $y /(1-y)=1.0$. The reciprocal of the dilution of $C^{\prime}$ used was divided by the number of milliliters of this dilution of $\mathrm{C}^{\prime}$ required for $50 \%$ lysis to give the complement lysis sensitivity titer $\left(\mathrm{C}^{\prime} \mathrm{LS} \mathrm{H}_{50}\right.$ ), i.e., the dilution of $\mathrm{C}^{\prime}, 1 \mathrm{ml}$ of which will lyse $50 \%$ of the cells present. For example, in Figure 1, the plotted line intersects the $50 \%$ lysis point $[y /(1-y)$ $=1]$ at a complement concentration equivalent to $82 \mathrm{ml}$ of a $1 / 100$ dilution of whole serum. Hence the complement lysis sensitivity titer $\left(\mathrm{C}^{\prime} \mathrm{LS} \mathrm{H}_{50}\right)=100 / 82=1.18 \mathrm{U}$.

When $\mathrm{PNH}$ cells were analyzed by this test, complex curves resulted which suggested that these cells consist of two populations that differ in their sensitivity to complement lysis (see Figure 2). To determine by hand calculation the sensitivity titer of each population separately, we estimated the proportion of each population from the inflection point of the curve. The value of $y /(1-y)$ at that point was converted to the corresponding value of $y$ by the formula:

$y=\frac{y /(1-y)}{1+[y /(1-y)]}$. 
This result estimates the proportion of all cells that are in the sensitive population.

The fraction of the population of sensitive cells lysed by a given amount of complement was then determined by application of the following formula (only values between 0 and 1.0 represent lysis of sensitive cells): $y_{\text {sensitive }}=$ [optical density of supernatant $\mathrm{t}_{411} \mathrm{~m} \mu$ (corrected)]/(optical density $\left._{\text {total }} \times R\right)$, where $R=$ the fraction of all cells in the sensitive population, and optical density tota1 = optical density at $541 \mathrm{~m} \mu$ of all cells lysed in $0.04 \% \mathrm{NH}_{4} \mathrm{OH}$.

The fraction of the insensitive population lysed by a given concentration of complement was determined by the following formula: $y_{\text {insensitive }}=$ [optical density of supernatant $_{541} \mathrm{~m} \mu-$ (optical density tot $_{\mathrm{a} 1} \times R$ )] / [optical density $\left._{\text {tota1 }} \times(1-R)\right]$. These data were then plotted separately for sensitive and insensitive cells after applying the Von Krogh correction. The amount of complement yielding $50 \%$ lysis of each population was then determined as for normal cells (see above).

Computer analysis of data from PNH patients. The data derived from the complement lysis sensitivity tests of the red cells of eight patients with $\mathrm{PNH}$ were analyzed by the IBM 7094 computer, by a general purpose program (11). The data were fitted by the least squares method to equations describing a combination of two gaussian curves and a linear term:

$$
\begin{gathered}
q=A_{1} f_{1}+A_{2} f_{2}+A_{3} y, \\
f_{1}(X)=\frac{1}{\sigma_{1} \sqrt{2}} \int_{0}^{y} \mathrm{e}^{-\left(\mathrm{t}-X_{1}\right)^{2} / 2 \sigma_{1} \sqrt{2}} \mathrm{dt}, \text { and } \\
f_{2}(X)=\frac{1}{\sigma_{2} \sqrt{2}} \int_{0}^{y} \mathrm{e}^{-\left(\mathrm{t}-X_{2}\right)^{2} / 2 \sigma \sqrt{2}} \mathrm{dt},
\end{gathered}
$$

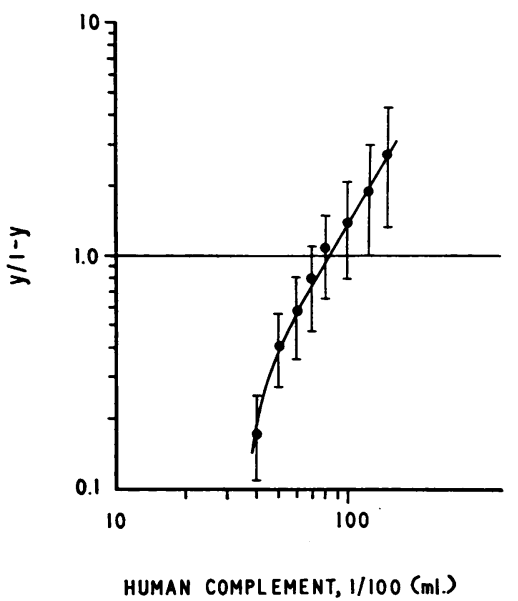

Fig. 1. The lysis by graded amounts of human COMPLEMENT OF NORMAL CELLS SENSITIZED WITH THE "Optimal" amount of ANTI-I antibody. The data are evaluated by the logarithmic transformation of the Von Krogh equation: $y=$ fraction of cells lysed. The points represent the mean values of ten tests; the bars delimit $1 \mathrm{SD}$ on each side of the mean.

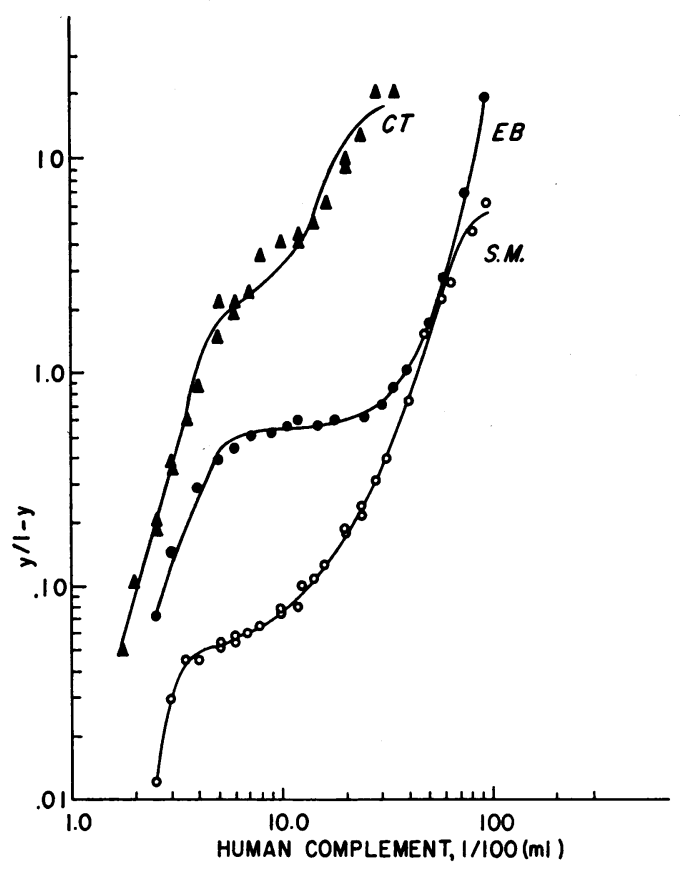

Fig. 2. Representative curves illustrating the LYSIS OF PAROXYSMAL NOCTURNAL HEMOGLOBINURIA (PNH) RED CELLS BY ANTI-I ANTIBODY AND HUMAN C'. The complement lysis of the curves of cells of three patients with clinical disease of different severity is shown. The initials correspond to those used in Tables I and III. The lines shown are the least squares lines defined by the IBM 7094 computer from the experimental points given in each case.

where $y=$ concentration of complement, $X_{1}=$ the mean of the distribution for the sensitive population (1), $X_{2}=$ the mean of the distribution for the insensitive population (2), $\sigma_{1}$ and $\sigma_{2}=$ the standard deviations of populations 1 and 2, respectively, and $A_{1}$ and $A_{2}=$ the relative contributions of populations 1 and 2 to the sum. The term $A_{3} y$ was introduced to permit the compensation of a slight apparent constant upward drift of the ordinate when present in the data. The functions $f_{1}$ and $f_{2}$ are normalized so that

$\int_{0}^{\infty} f_{1} \mathrm{~d} \mathbf{x}=1$

Differential density centrifugation of cells. Cells of different and known density were obtained by the differential density centrifugation technique of Danon and Marikovsky (12)..$^{6}$ Mixtures of dimethylphthalate and di- $\boldsymbol{n}$ butyl phthalate that had a specific gravity ranging from 1.094 to 1.074 were mixed with cells and centrifuged. Cells lighter than the immiscible mixture were above it, those heavier below. By appropriate selection of cells and mixtures of oil, we obtained red cells with a fairly narrow range of specific gravity. The sensitivity to com-

6 These separations were kindly performed by Dr. S. M. Lewis and Miss Margaret Cox. 
plement lysis of each of these fractions was determined separately.

The four-tube complement lysis sensitivity test (using the anti-I antibody). Into four large test tubes labeled 1 through 4 were pipetted, respectively, 1) $5.5 \mathrm{ml} \mathrm{VSB}$, 2) $6.5 \mathrm{ml} \mathrm{VSB}, 3) 5.5 \mathrm{ml} \mathrm{VSB}$, and 4) $6.5 \mathrm{ml} 0.05 \%$ $\mathrm{NH}_{4} \mathrm{OH}$, and the tubes were placed in a melting ice bath. A standard suspension of red cells was prepared as above (or alternatively $0.2 \mathrm{ml}$ of washed, packed red cells was added to $10 \mathrm{ml}$ of $\mathrm{VSB}$ ), and after cooling in the ice bath, $2.5 \mathrm{ml}$ was mixed with $2.5 \mathrm{ml}$ anti-I antibody diluted 1 part in 40 with cold VSB. One $\mathrm{ml}$ of these sensitized cells was pipetted at once into each of the four tubes. One $\mathrm{ml}$ of diluted fresh normal human serum (1 part serum +9 parts VSB) was immediately pipetted into the first tube. One $\mathrm{ml}$ of whole fresh normal human serum was pipetted into the third tube. The contents of the tubes were mixed and incubated at $0^{\circ} \mathrm{C}$ for $12 \mathrm{~min}$ utes with occasional mixing to maintain the cells in uniform suspension. They were then placed in a $37^{\circ} \mathrm{C}$ water bath and incubated for 1 hour. After separating the unlysed cells by centrifugation, we estimated the amount of hemolysis as above. Blanks for correction for color due to complement were prepared by adding $1.0 \mathrm{ml}$ of whole serum, respectively, to $6.5 \mathrm{ml}$ of VSB. If excessive hemolysis (more than $5 \%$ ) occurred in the second tube or if no hemolysis occurred in the third tube, the test was considered invalid. If hemolysis occurred in the first tube in excess of that in the second tube, a sensitive population of cells was present. The net percentage of hemolysis in this tube was calculated; this represented an estimate of the proportion of sensitive cells in the blood sample.

\section{Results}

Determination of the amount of antibody yielding maximal $C^{\prime}$ activity (optimal dilution of antibody). The dilution of antibody yielding maximal $C^{\prime}$ activity is given in Table II for several antibodies with normal, papainized normal, and $\mathrm{PNH}$ cells. In the experiments reported below, the optimal dilution of each antibody for sensitizing normal cells was used in sensitizing normal, $\mathrm{PNH}$, and papainized red cells unless otherwise noted in

TABLE II

Highest dilution of antibody yielding the greatest amount of lysis with a given amount of complement ("optimal" dilution of antibody) determined for normal and PNH cells

\begin{tabular}{lccc}
\hline \hline & \multicolumn{3}{c}{ Red cells } \\
\cline { 2 - 4 } \multicolumn{1}{c}{ Antibody } & Normal & PNH & $\begin{array}{c}\text { Papainized } \\
\text { normal }\end{array}$ \\
\hline Anti-I & $1 / 40$ & $1 / 200-1 / 600$ & $1 / 160$ \\
Anti-p (isoantibody) & $1 / 4$ & $1 / 16$ & \\
Donath-Landsteiner & $1 / 10$ & $1 / 80$ & \\
Shigella-anti-Shigella & $1 / 40$ & & \\
\hline
\end{tabular}

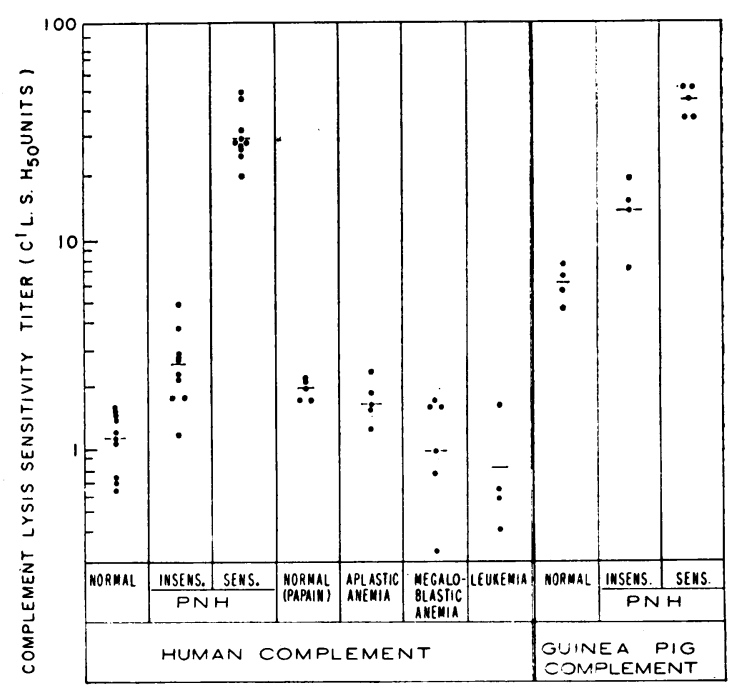

Fig. 3. A COMPARISON OF THE COMPLEMENT LYSIS SENSITIVITY TITERS OF VARIOUS RED CELLS SENSITIZED WITH THE SAME AMOUNT OF ANTI-I ANTIBODY AND LYSED WITH HUMAN OR GUINEA PIG COMPLEMENT. The bars represent the mean values of the determinations of each group.

order to keep in constant excess the amount of antibody in all tests.

Complement sensitivity of normal red cells. The lysis of sensitized normal red cells by increments of complement is illustrated in Figure 1. In most experiments, a straight line resulted when the logarithm of $y /(1-y)$ (where $y$ is the fraction of cells lysed) was plotted against the logarithm of complement concentration. Occasionally, the line curved slightly at high $\mathrm{C}^{\prime}$ concentrations. The complement lysis sensitivity titers $\left(\mathrm{C}^{\prime} \mathrm{LS} \mathrm{H}_{50}\right.$ ) with human $\mathrm{C}^{\prime}$ and anti-I antibody of ten determinations on the cells of nine normal donors, calculated as above, are shown in Figure 3.

The complement sensitivity of normal red cells was greater when guinea pig serum was used as a source of complement (Figure 3 ). The complement lysis sensitivity titers, with human $C^{\prime}$, of normal cells when the Donath-Landsteiner antibody, anti- $\mathrm{p}^{\mathrm{k}}$ isoantibody, and Shigella passive lysis system were used for sensitization are shown in Figure 4.

Sensitivity to complement lysis of red cells in hematological diseases other than $P N H$. The $\mathrm{C}^{\prime}$ lysis sensitivity titers (with normal human $\mathrm{C}^{\prime}$ and anti-I antibody) of red cells of patients with a variety of diseases other than $\mathrm{PNH}$ are shown in Figure 3. Values significantly greater than nor- 


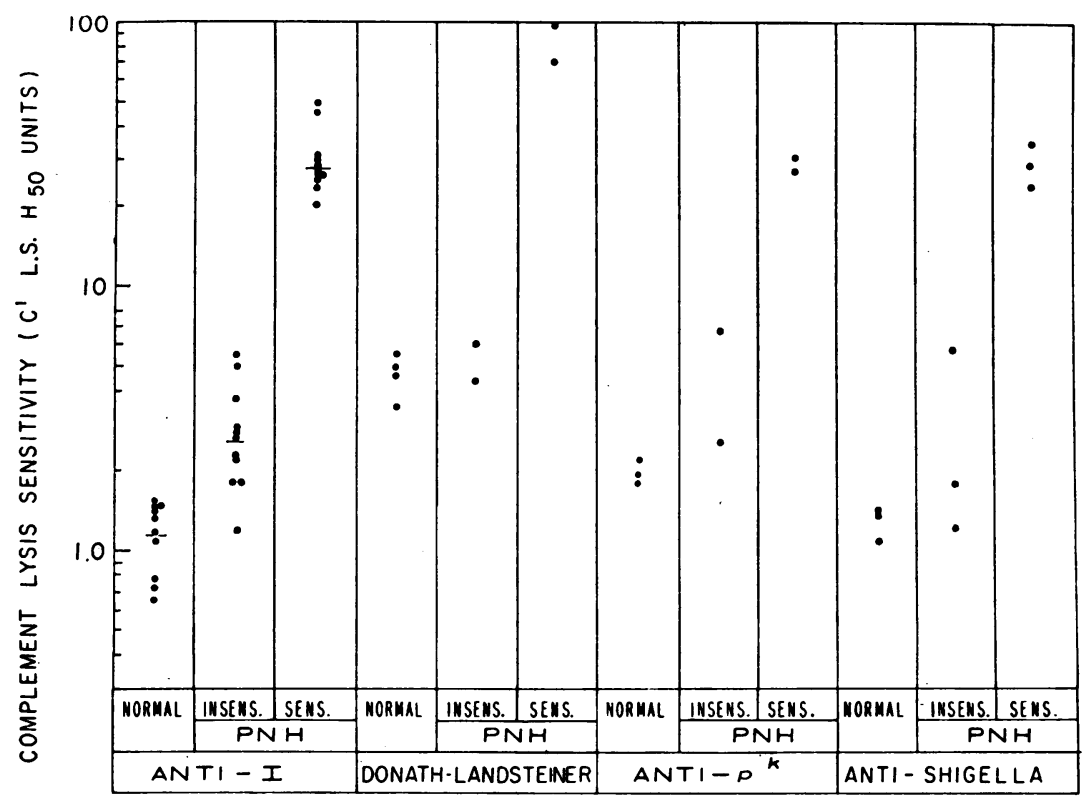

Fig. 4. A COMPARISON OF THE COMPLEMENT LYSIS SENSITIVITY TITERS OF NORMAL AND PNH RED CELLS SENSITIZED WITH VARIOUS ANTIBODIES AND LYSED WITH HUMAN COMPLEMENT. $\mathrm{C}^{\prime} \mathrm{LS} \mathrm{H}_{\mathrm{so}}$ is the dilution of $\mathrm{C}^{\prime}, 1 \mathrm{ml}$ of which will lyse $50 \%$ of the cells present.

mal were observed only with cells from patients with aplastic anemia.

Sensitivity to complement lysis of PNH cells. Hemolysis of $\mathrm{PNH}$ cells by increasing amounts of $\mathrm{C}^{\prime}$ does not occur as a simple function of the concentration of $\mathrm{C}^{\prime}$ as with normal cells. In every instance (except patient A.H., considered to have undergone complete remission of the disease) (13, 14), when the logarithm of $y /(1-y)$ was plotted against the logarithm of $C^{\prime}$ concentration, there appeared to be two connected, nearly parallel straight-line portions of the curve (Figure 2). This is interpreted to mean that $\mathrm{PNH}$ cells consist of two populations of cells, one of which is lysed by very small amounts of $\mathrm{C}^{\prime}$, the other requiring more $\mathrm{C}^{\prime}$ for lysis. The data obtained from hemolysis of $\mathrm{PNH}$ cells were analyzed by two methods: 1) The "hand calculation" method, which involved an analysis using the Von Krogh transformation (see above), and 2) the computer method in which an IBM computer was used to fit the data to a curve describing the sum of two curves of normal distribution. The Von Krogh transformation is an empirical equation that approximately describes the middle range of the curve of normal distribution but deviates markedly at extremes from the mean. When an attempt was made by the computer to fit the data from lysis of PNH cells to an equation derived from the Von Krogh equation, significant systematic deviations of the data points from the least squares line were noted. Since no such deviations were seen when the equation involving the integral form of the gaussian equation of normal distribution was used to analyze the data, this probably represents a more precise mathematical treatment of the data.

The complement lysis sensitivity titers as determined both by hand calculation and by computer analysis (when done) of the cells of 11 patients with PNH are presented in Table III. Lysis was brought about in all cases by anti-I antibody and human complement. Examples of the curves obtained with the cells of three patients are shown in Figure 2; the correspondence between the least squares line as determined by the computer and the observed values is good. There is good correlation between the results of hand calculation and computer analysis in determining the sensitivity titer of the sensitive population, but the correlation between hand-calculated values and computer-obtained values is not as good for deter- 
minations of the sensitivity titer of the insensitive population. In all cases, the values obtained by computer analysis were higher than those obtained by hand calculation. There is a consistent small underestimation of the proportion of cells that is sensitive when the hand calculation method is used as compared to the computer method. These findings indicate that the analysis of the data obtained from complement lysis sensitivity tests on $\mathrm{PNH}$ cells by computer is useful and precise but that simpler hand calculation methods yield comparable results that are more easily obtained.

The complement sensitivity of the sensitive population of $\mathrm{PNH}$ cells was the same when the cells were sensitized with antibody diluted $1 / 40$ as when diluted 1/200 (the optimum for $\mathrm{PNH}$ cells).

The above data were derived from patients before transfusion. The presence of transfused cells in $\mathrm{PNH}$ patients may be detected by the complement lysis sensitivity test, as illustrated in Figure 5. The effect of papainization in increasing the sensitivity to lysis of these three populations is illustrated in the same Figure.

The complement lysis sensitivity titers of PNH cells with guinea pig serum (with anti-I antibody) and iso-anti- $\mathrm{p}^{\mathrm{k}}$ or the Donath-Landsteiner antibody and the passive lysis system with Shigella polysaccharide and rabbit antibody (all with human complement) are summarized in Figures 3 and 4. There was evidence of two populations of cells in each instance.

Complement lysis sensitivity related to cell age. To show that differences in sensitivity between the two populations of $\mathrm{PNH}$ cells are not a reflection of the age of the cells, we separated cells of specific densities by means of mixtures of di- $n$-butyl phthalate and dimethyl phthalate according to the method of Danon and Marikovsky (12). The complement lysis sensitivity of each fraction was then tested. When PNH cells were used, the two populations were found in all fractions. The largest proportion of sensitive cells was found in the least dense (youngest) fraction, and the sensitivity of this population increased with density (Table IV). When normal cells were separated and tested in the same manner, it was found that, although the sensitivity to complement lysis increased slightly with age, only a single population was present in each of the fractions (Table IV).

Relation of complement lysis sensitivity to lysis in acidified normal serum (Ham's test). In Table III, the proportion of sensitive cells determined by analysis of the complement lysis sensitivity curves is compared with the results of the acidified serum lysis test on the same PNH blood. In some cases the proportion of abnormal cells as determined by inflection point analysis is similar to the amount of hemolysis observed by treat-

TABLE III

Summary of complement lysis sensitivity analysis of the red cells of patients with PNH

\begin{tabular}{|c|c|c|c|c|c|c|c|c|}
\hline \multirow[b]{3}{*}{ Patient } & \multicolumn{4}{|c|}{ Complement lysis sensitivity titer } & \multicolumn{3}{|c|}{$\begin{array}{c}\text { Proportion of cells in sensitive } \\
\text { population }\end{array}$} & \multirow[b]{3}{*}{$\begin{array}{l}\% \text { lysis in } \\
\text { acidified serum }\end{array}$} \\
\hline & \multicolumn{2}{|c|}{ Sensitive cells } & \multicolumn{2}{|c|}{ Insensitive cells } & \multirow{2}{*}{$\begin{array}{l}\text { By inflec- } \\
\text { tion point } \\
\text { analysis }\end{array}$} & \multirow{2}{*}{$\begin{array}{l}\text { By com- } \\
\text { puter } \\
\text { analysis }\end{array}$} & \multirow{2}{*}{$\begin{array}{c}\text { By comple- } \\
\text { ment lysis } \\
\text { sensitivity } \\
\text { test (4-tube) }\end{array}$} & \\
\hline & $\begin{array}{l}\text { Hand cal- } \\
\text { culation }\end{array}$ & $\begin{array}{l}\text { Computer } \\
\text { analysis }\end{array}$ & $\begin{array}{l}\text { Hand cal- } \\
\text { culation }\end{array}$ & $\begin{array}{l}\text { Computer } \\
\text { analysis }\end{array}$ & & & & \\
\hline & \multicolumn{4}{|c|}{$C^{\prime} L S H_{50} U^{*}$} & $\%$ & $\%$ & $\%$ & \\
\hline $\begin{array}{l}\text { C.T. } \\
\text { K.P. } \\
\text { C.L. } \\
\text { B.G. } \\
\text { M.B. } \\
\text { H.H. } \\
\text { J.S. } \\
\text { S.M. } \\
\text { K.H.D. } \\
\text { H.M. } \\
\text { A.H. }\end{array}$ & $\begin{array}{l}27 \\
24 \\
28 \\
27 \\
27 \\
47 \\
29 \\
32 \\
40 \\
20 \\
+\end{array}$ & $\begin{array}{l}31 \\
24 \\
31 \\
28 \\
28 \\
48 \\
31 \\
35\end{array}$ & $\begin{array}{l}5.0 \\
2.3 \\
3.8 \\
2.9 \\
1.8 \\
2.7 \\
1.8 \\
2.2 \\
2.8 \\
1.2 \\
1.3\end{array}$ & $\begin{array}{l}9.3 \\
3.8 \\
\\
4.8 \\
1.9 \\
2.8 \\
2.7 \\
2.5\end{array}$ & $\begin{array}{c}81 \\
50 \\
46 \\
42 \\
37 \\
27 \\
23 \\
6.2 \\
5.2 \\
3.5\end{array}$ & $\begin{array}{l}90 \\
45 \\
49 \\
45 \\
39 \\
27 \\
\\
\\
10\end{array}$ & $\begin{array}{r}46 \\
44 \\
37 \\
\\
23 \\
\\
5.4 \\
3.5\end{array}$ & $\begin{array}{l}86 \\
33 \\
25 \\
42 \\
14 \\
22 \\
18.3 \\
3.0 \\
0 \\
0 \\
\dagger\end{array}$ \\
\hline $\begin{array}{l}\text { Mean } \\
\text { SD }\end{array}$ & $\begin{array}{r}30.1 \\
7.9\end{array}$ & $\begin{array}{r}31.9 \\
7.2\end{array}$ & $\begin{array}{l}2.5 \\
1.1\end{array}$ & $\begin{array}{l}4.0 \\
2.5\end{array}$ & & & & \\
\hline
\end{tabular}

* $\mathrm{C}^{\prime} \mathrm{LS} \mathrm{H}_{50}=$ the dilution of $\mathrm{C}^{\prime}, 1 \mathrm{ml}$ of which will lyse $50 \%$ of the cells present.

$\dagger$ No sensitive cells present; the acidified serum test has been negative since 1949 (13). 
IMMUNE LYSIS OF NORMAL AND PNH RED CELLS. I. SENSITIVITY OF PNH CELLS

TABLE IV

Summary of complement sensitivity titrations of cells of graded density

\begin{tabular}{|c|c|c|c|c|c|c|}
\hline Cells & Fraction & Density & $\begin{array}{c}\text { \%eticulo- } \\
\text { cytes }\end{array}$ & $\begin{array}{l}\text { Sensi- } \\
\text { tive } \\
\text { cells }\end{array}$ & $\begin{array}{l}\text { Insen- } \\
\text { sitive } \\
\text { cells }\end{array}$ & $\begin{array}{l}\% \text { Sen- } \\
\text { sitive } \\
\text { cells }\end{array}$ \\
\hline & & & & \multicolumn{2}{|c|}{$C^{\prime} L S H_{s 0} U$} & \\
\hline PNH & $\begin{array}{l}1 \\
2 \\
3 \\
4\end{array}$ & $\begin{array}{c}1.074 \\
1.074-1.082 \\
1.082-1.086 \\
1.086\end{array}$ & $\begin{array}{l}36 \\
7.2 \\
4.6 \\
1.8\end{array}$ & $\begin{array}{l}28 \\
35 \\
40 \\
42\end{array}$ & $\begin{array}{l}3.4 \\
3.4 \\
4.3 \\
5.4\end{array}$ & $\begin{array}{l}70.0 \\
50.0 \\
38.4 \\
35.7\end{array}$ \\
\hline Normal & $\begin{array}{l}1 \\
2 \\
3\end{array}$ & $\begin{array}{c}1.090 \\
1.090-1.094 \\
1.094\end{array}$ & $\begin{array}{l}6.0 \\
0.02 \\
0.01\end{array}$ & & $\begin{array}{l}1.1 \\
1.2 \\
1.3\end{array}$ & \\
\hline
\end{tabular}

ment of the cells with acidified serum. This suggests that it is the sensitive cells that are lysed by this procedure. This is, in fact, only partially true as is shown by the analysis of the sensitivity to $\mathrm{C}^{\prime}$ lysis of PNH cells before and after lysis by acidi-

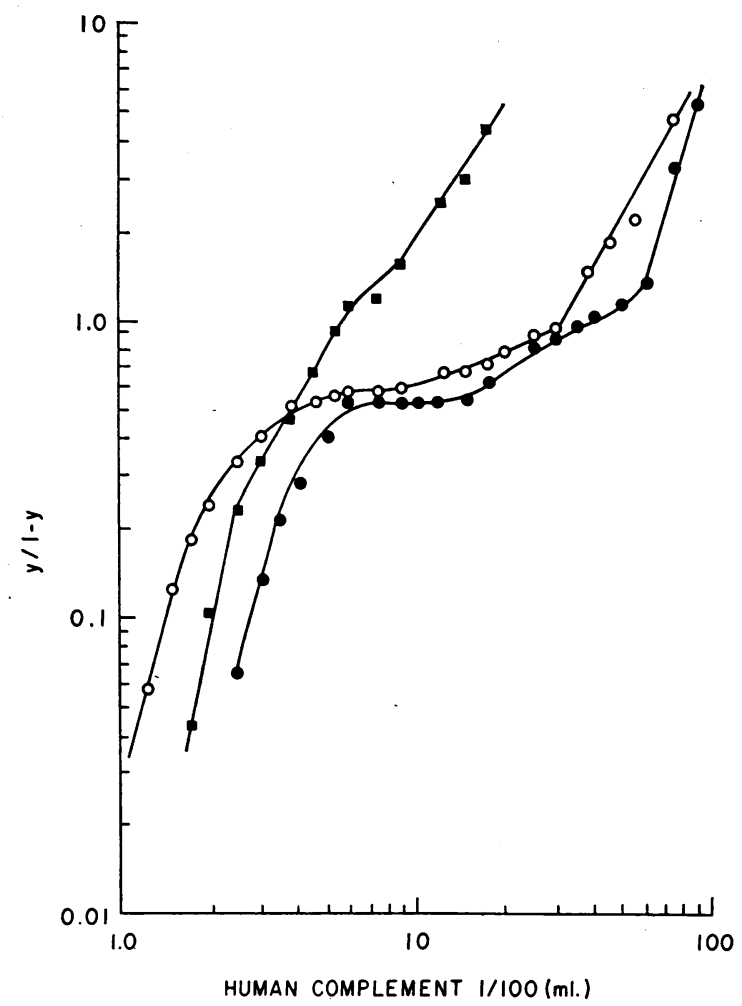

Fig. 5. The lysis by human $C^{\prime}$ and anti-I antiBODY OF THE CELLS OF A PATIENT WITH PNH WHO HAD BEEN TRANSFUSED, ILLUSTRATING THE PRESENCE OF THREE DISTINCT POPULATIONS. - , cells sensitized with anti-I antibody and lysed by human $\mathrm{C}^{\prime} ; \mathrm{O}$, papainized cells sensitized with anti-I antibody and lysed by human $C^{\prime}$; $\boldsymbol{\square}$, cells sensitized with anti-I antibody and lysed by guinea pig $\mathrm{C}^{\prime}$. fied serum (Table V). There is a marked reduction in the proportion of sensitive cells after this treatment, but a portion of this population remains. There is a reduction in the mean sensitivity of this sensitive population, and in one instance, in the sensitivity of the insensitive cells as well. This suggests that a majority of the cells lysed by acidified serum are of the sensitive population, but this medium does not lyse all such cells and probably lyses some insensitive cells.

The four-tube complement lysis sensitivity test. The results of the use of the four-tube complement lysis sensitivity test, a simplified version of the complete complement lysis sensitivity test, in the analysis of PNH cells are shown in Table III. No positive results have been found in testing the cells of 10 normal donors or of 12 patients with hematological disease other than $\mathrm{PNH}$. The sensitive population was easily demonstrated in those patients with $\mathrm{PNH}$ in which the acidified serum test was negative. There is good correlation between the results of this test and the more complicated inflection point analysis. The finding that a passive lysis system such as the Shigella-antiShigella system gives the same results in the com-

TABLE V

Complement sensitivity titers (anti-I, human $C^{\prime}$ ) of $P N H$ cells before and after acidified serum lysis

\begin{tabular}{|c|c|c|c|c|}
\hline \multirow{2}{*}{\multicolumn{2}{|c|}{ Patient }} & \multicolumn{2}{|c|}{$\begin{array}{l}\text { Complement sensi- } \\
\text { tivity titer }\end{array}$} & \multirow[b]{2}{*}{$\begin{array}{l}\% \text { of sensi- } \\
\text { tive cells }\end{array}$} \\
\hline & & $\begin{array}{c}\text { Sensitive } \\
\text { cells }\end{array}$ & $\begin{array}{c}\text { Insensitive } \\
\text { cells }\end{array}$ & \\
\hline \multicolumn{5}{|c|}{$C^{\prime} L S H_{50} U$} \\
\hline B.G. & $\begin{array}{l}\text { Before } \\
\text { After }\end{array}$ & $\begin{array}{l}27 \\
24\end{array}$ & $\begin{array}{l}2.9 \\
1.3\end{array}$ & $\begin{array}{l}42 \\
7.6\end{array}$ \\
\hline H.H. & $\begin{array}{l}\text { Before } \\
\text { After }\end{array}$ & $\begin{array}{l}47 \\
24\end{array}$ & $\begin{array}{l}2.7 \\
2.8\end{array}$ & $\begin{array}{r}27 \\
4.0\end{array}$ \\
\hline
\end{tabular}


plement lysis sensitivity test as iso- and autoantibodies would indicate that easily available materials could be used for the four-tube $C^{\prime}$ lysis sensitivity test.

\section{Discussion}

Differences in the sensitivity of human red cells to complement lysis have been previously described. Ham and Dingle in 1939 recognized that $\mathrm{PNH}$ cells are lysed more easily by hetero- and isoantibodies than normal cells, i.e., $\mathrm{PNH}$ cells are lysed at higher dilutions of antibody when the amount of complement is constant (1). Red cells treated with trypsin, papain, ficin, or other proteolytic enzymes are also more sensitive than normal cells to complement lysis (15). More recently, Dacie, Lewis, and Tills (16) showed that the red cells of patients with a variety of hematological diseases are lysed more readily by anti-I antibody in the presence of large amounts of $\mathrm{C}^{\prime}$ than normal cells, although considerably less readily than the cells of most patients with $\mathrm{PNH}$, particularly when the antiserum is diluted.

The techniques used in the present studies permit the extension, confirmation, and quantitation of these observations. The complement lysis sensitivity test, as used here, does not distinguish between sensitivity to complement and sensitivity to antibody, but rather measures the sensitivity of the cells to the whole series of reactions between antigen, antibody, and complement components. Some of the reasons for the variation among different types of cells in sensitivity to complement lysis delineated in the present paper will be discussed in full in the second paper of this series (17).

From these studies, it is apparent that normal cells consist of a single population of cells with respect to their sensitivity to $C^{\prime}$ lysis. In most cases, the plot of the logarithm of $\mathrm{C}^{\prime}$ concentration against the logarithm of $y /(1-y)$ was a straight line; however, in some instances, there was slight curvature in the line at higher concentrations of complement, suggesting that either some of the cells were not equally sensitized or that high concentrations of serum had an inhibitory effect on the action of complement. The latter possibility is consonant with the fact that there is a known naturally occurring inhibitor of the first component of complement $\left(C^{\prime} 1\right)$ in normal serum (18). Further, when these normal cells were papainized, when guinea pig serum was used as a source of $\mathrm{C}^{\prime}$, or when the Donath-Landsteiner antibody was used for sensitization, less serum was required for lysis, and curvature of the line did not occur.

In their studies of the lysis of cells of patients with a variety of hematological disorders by anti-I cold agglutinin, Dacie and his colleagues (16) found that the cells of patients with leukemia, aplastic anemia, and megaloblastic anemia are lysed, in the presence of excess complement, by smaller concentrations of antibody than are required to lyse normal cells. When a small number of patients with these diseases were investigated by the present technique, a single population of cells was seen in each sample, and a somewhat wider than normal variation in the complement sensitivity titers was noted. However, only with the cells of patients with aplastic anemia who had not been transfused was the complement sensitivity titer consistently higher than normal, and in some cases it equaled or exceeded the sensitivity of the insensitive population of $\mathrm{PNH}$ cells. This finding is of particular interest, since aplastic anemia and $\mathrm{PNH}$ are apparently related; that is, a certain number of patients with $\mathrm{PNH}$ appear initially to have typical aplastic anemia, and the abnormality specific for $\mathrm{PNH}$ as estimated by the acidified serum lysis test becomes manifest only after a period of time $(14,19-22)$.

In this regard, mention should be made of one patient, K.H.D., in the present series of $\mathrm{PNH}$ patients. He presented with a clinical syndrome typical of aplastic anemia and required repeated transfusions. The routine acidified serum lysis test was negative, and the urinary sediment contained no hemosiderin. However, on detailed analysis of his cells with the complement lysis sensitivity titration, a small proportion of his cells was found to be abnormally sensitive to lysis by $\mathrm{C}^{\prime}$, and the diagnosis of $\mathrm{PNH}$ was made. The routine acidified serum lysis test later became clearly positive. Further studies over a period of time in this and similar patients, as well as in a larger group of patients with hematological disease, are currently in progress.

The present studies amply confirm that the cells in patients with paroxysmal nocturnal hemoglobinuria are more sensitive to the effects of antibody and complement than normal human cells. This is seen when the amount of antibody is limiting as in 
the determination of the optimal antibody concentration but more markedly when the antibody is in excess and the amount of complement is limiting as in the complement lysis sensitivity test. Under these conditions two populations of cells are clearly shown, one of which requires about onetwenty-fifth, the other about one-half the amount of complement for lysis of $50 \%$ of the cells as normal cells.

The finding of two such discrete populations of cells in PNH explains the previously noted wide variability of the cells of patients with the disease. It has been suggested that some of the cells in $\mathrm{PNH}$ blood might be normal from the fact that there is a residuum of cells that resists lysis in the acidified serum test even if the cells are exposed to successive samples of acidified serum (22). Also, complex red cell survival curves have been repeatedly noted with $\mathrm{PNH}$ cells both with Ashby differential agglutination and radioisotope techniques $(23,24)$. However, it was not known whether this variability in the rate of destruction in vivo and the insensitivity of some of the cells to acidified serum lysis in vitro was a reflection of a single population of cells with a wide distribution in the severity of the abnormality or of two populations of cells. It is quite apparent from our studies that the cells are of two populations. Each population appears to have a narrow range of sensitivity to complement lysis.

Further, these studies indicate that the "insensitive" cells are usually not, in fact, normal but are also somewhat more sensitive than normal cells to complement lysis. This means that PNH cannot simply be regarded as a mosaic of abnormal cells proliferating along with normal cells but, in most cases, as a mosaic of two abnormal types of cells. The distinctness of the sensitive population and the similarity in the complement lysis sensitivity titers of sensitive cells from different patients suggest that the abnormality characteristic of $\mathrm{PNH}$ is either present or absent in a given cell and that the result of the presence of the abnormality is always the same, i.e., a marked increase in the sensitivity of that cell to the effects of complement.

Differences in the sensitivity of cells to complement lysis is a characteristic of the cells themselves rather than a peculiarity of specific antibodies or complements. With normal cells there is rela- tively little difference in the amount of complement needed to lyse the same percentage of cells sensitized with several antibody systems, including the Shigella passive lysis system. With $\mathrm{PNH}$ cells two populations were evident regardless of the antibody used, and the amount of human complement needed for $50 \%$ lysis was similar for all antibodies tested. These findings suggest that the antibody plays only a minor role in determining the differences in sensitivity of $\mathrm{PNH}$ and normal cells and, as will be shown in a subsequent paper (17), the increased sensitivity to complement lysis depends mainly upon increased efficiency of complement, independent of antibody.

The sensitive population of cells is a distinguishing characteristic of $\mathrm{PNH}$. To date, no human red cells in normal conditions or in any other disease state have been found that are as sensitive to the effects of immune reactions. It is logical to suggest, therefore, that this sensitivity plays a role in the pathogenesis of the disease. Clinically, the severity of the hemolysis appears to be related, probably to a great extent, to the proportion and sensitivity of the sensitive cells. Obviously, factors in the serum environment of the patients may also affect the clinical state as is evidenced by the occurrence of sudden crises of hemolysis in most patients at some time in the course of their disease. Further, the clinical impact of the disease may depend upon factors other than intravascular hemolysis, such as the effects of erythrocytic hypoplasia, leukopenia, thrombocytopenia, or intravascular clotting.

The complement-sensitive cells survive in the circulation a shorter length of time than the insensitive cells. This is seen from the fact that the proportion of sensitive cells is greater in the least dense (youngest) group of cells. Kan and Gardner have shown that $\mathrm{PNH}$ reticulocytes, a population relatively rich in sensitive cells, do not survive as long as reticulocytes from patients with pernicious anemia who are given cyanocobalamine (25). Recent studies using glycine- $2-{ }^{14} \mathrm{C}$ as a label have shown directly that the population sensitive to complement is destroyed within 20 days whereas the insensitive population survives more nearly normally (26). This is in accord with evidence from the ${ }^{\mathrm{B}} \mathrm{Cr}$ studies in $\mathrm{PNH}$ if the biphasic curve is, in fact, due to the presence of two populations (24). 
The nature of the plasma factors responsible for the intravascular hemolysis of the $\mathrm{PNH}$ cells or for the in vitro lysis by acidified serum or for both has been the subject of prolonged controversy $(7,27,28)$. Regardless of the factors responsible for the initiation of the immune reaction (naturally occurring antibodies, properdin, fluidphase immune reactions, or whatever), it is now quite evident that the factor ultimately responsible for the destruction of cells in the acidified serum test is complement. In the third paper of this series (29), it is shown that the membrane defects responsible for lysis of $\mathrm{PNH}$ cells treated with acidified serum appear to be the same as those in cells treated with specific antibody and complement. Further, the nature of the sensitizing agent or agents, be they specific antibodies, cross-reacting antibodies, normal $\gamma$-globulin, or heterologous antigen-antibody reactions, is of relatively little importance whether at the cell surface or possibly in the fluid phase. The important difference between PNH cells and normal cells is the difference in sensitivity to lysis by $\mathrm{C}^{\prime}(17)$.

We propose, therefore, that both normal and PNH cells may react with factors in normal plasma that may result in the fixation of very small but probably equal amounts of complement or complement components $(1,17)$. In the case of normal cells, this is insufficient to bring about lysis. However, in the case of the sensitive PNH cells, even these small amounts of complement or complement components are sufficient to cause the intravascular hemolysis of the cell because of its remarkably increased sensitivity to immune lysis.

It appears likely, therefore, that the apparent uniquely increased sensitivity of PNH cells to lysis by antibody and $\mathrm{C}^{\prime}$ is fundamental to the pathogenesis of the disease.

\section{Summary}

1. The sensitivity to immune lysis of normal human red cells and red cells from a variety of disease states, especially paroxysmal nocturnal hemoglobinuria ( $\mathrm{PNH})$, has been estimated by a quantitative technique adapted from the standard assay for serum complement. This method depends' upon the estimation of the amount of complement required to lyse a given number of red cells sensitized by specific antibody.
2. Relatively large amounts of fresh serum are needed to lyse normal cells and the cells of patients with a variety of hematologic diseases. The cells of patients with aplastic anemia are somewhat more sensitive to complement lysis than normal, i.e., they require somewhat less serum for lysis.

3 . The cells of patients with paroxysmal nocturnal hemoglobinuria are markedly sensitive to lysis by complement and antibody. In the blood of each of ten patients, two populations of red cells were found, one of which (the "sensitive" population) required about one-twenty-fifth as much complement as normal cells for lysis of an equal proportion of the cells. The difference in sensitivity of the sensitive population is seen with a variety of antibodies and with both human and guinea pig complement. The other population (the "insensitive" population) required a mean of one-half as much $C^{\prime}$ as normal cells for lysis. When PNH cells are fractionated according to density, sensitive cells are present in all fractions and in the highest proportion in the least dense (youngest) cells.

4. The proportion of sensitive and insensitive cells could be estimated from the data, and this proportion was found to vary from patient to patient. There is a rough correlation between the proportion and sensitivity of the sensitive population of cells and the severity of the hemolytic process.

5. The acidified serum lysis (Ham's) test was found to lyse largely the sensitive population of cells. However, some cells in this population were not lysed, and some cells in the insensitive population were lysed by acidified serum. In two patients, a sensitive population of cells was present that was not detected by the acidified serum lysis test. A simplified version of the complement lysis sensitivity test is described that is more accurate than Ham's test in the detection and quantitation of the proportion of cells in the sensitive population.

6. These findings indicate that the sensitivity of the cells in $\mathrm{PNH}$ to complement lysis is fundamental to the pathogenesis of the disease. We suggest that as red cells, both normal and $\mathrm{PNH}$, circulate, small amounts of complement are fixed to them by factors present in normal serum, Because of the marked sensitivity of the sensitive population of PNH cells to complement lysis, they are 
destroyed intravascularly by complement, whereas normal cells, being much less sensitive, are not.

\section{Acknowledgments}

We wish to express our gratitude to Dr. Mones Berman and Mrs. Marjory Weiss of the National Institute of Arthritis and Metabolic Diseases for their invaluable help in the problems involving the IBM computer. We also wish to express our thanks to Dr. John Humphrey, National Institute for Medical Research, Mill Hill, and to Dr. Sheila Worlledge and Dr. S. M. Lewis, Department of Haematology, Postgraduate Medical School, London, for their help in acquiring various antibodies and cells. Also, much thanks is due to Drs. H. J. Rapp and Tibor Borsos, Immunochemistry Section, Immunology Branch, National Cancer Institute, for their help in teaching to one of us (W. F. R.) the principles of quantitative investigations with complement.

\section{References}

1. Ham, T. H., and J. H. Dingle. Studies on destruction of red blood cells. II. Chronic hemolytic anemia with paroxysmal nocturnal hemoglobinuria: certain immunological aspects of the hemolytic mechanism with special reference to serum complement. J. clin. Invest. 1939, 18, 657.

2. Dacie, J. V. Diagnosis and mechanism of hemolysis in chronic hemolytic anemia with nocturnal hemoglobinuria. Blood 1949, 4, 1183.

3. Dacie, J. V., and G. C. de Gruchy. Auto-antibodies in acquired haemolytic anaemia. J. clin. Path. 1951, 4, 253.

4. Hinz, C. F., Jr., M. E. Picken, and I. H. Lepow. Studies on immune human hemolysis. I. The kinetics of the Donath-Landsteiner reaction and the requirement for complement in the reaction. J. exp. Med. 1961, 113, 177.

5. Ham, T. H. Chronic hemolytic anemia with paroxysmal nocturnal hemoglobinuria: study of the mechanism of hemolysis in relation to acid-base equilibrium. N. Engl. J. Med. 1937, 217, 915.

6. Dacie, J. V., and N. Richardson. The influence of $\mathrm{pH}$ on in-vitro hæmolysis in nocturnal hæmoglobinuria. J. Path. Bact. 1943, 55, 375.

7. Hinz, C. F., Jr., W. S. Jordan, Jr., and L. Pillemer. The properdin system and immunity. IV. The hemolysis of erythrocytes from patients with paroxysmal nocturnal hemoglobinuria. J. clin. Invest. 1956, 35, 453.

8. Mayer, M. M. Complement and complement fixation in Experimental Immunology, 2nd ed., E. A. Kabat and M. M. Mayer, Eds. Springfield, Ill., Charles C Thomas, 1961, a) p. 133, b) p. 149, c) p. 150.

9. Davies, D. A. L., W. T. J. Morgan, and W. Mosimann. Studies in immunochemistry. 13. Preparation and properties of the " $O$ " somatic antigen of
Shigella dystenteriae (Shiga). Biochem. J. 1954, $56,572$.

10. Dacie, J. V., and S. M. Lewis. Practical Haematology, 3rd ed. London, J. and A. Churchill, 1963, p. 147.

11. Berman, M., E. Shahn, and M. F. Weiss. The routine fitting of kinetic data to models: a mathematical formalism for digital computers. Biophys. J. 1962, 2, 275.

12. Danon, D., and Y. Marikovsky. Determination of density distribution of red cell population. J. Lab. clin. Med. 1964, 64, 668.

13. Dacie, J. V., and A. Gilpin. Refractory anaemia (Fanconi type). Its incidence in three members of one family, with in one case a relationship to chronic haemolytic anaemia with nocturnal haemoglobinuria (Marchiafava-Micheli disease or "nocturnal haemoglobinuria"). Arch. Dis. Childh. $1944,19,155$.

14. Dacie, J. V., and S. M. Lewis. Paroxysmal nocturnal haemoglobinuria: variation in clinical severity and association with bone-marrow hypoplasia. Brit. J. Haemat. 1961, 7, 442.

15. Yachnin, S., M. T. Laforet, and F. H. Gardner. $\mathrm{pH}$ dependent hemolytic systems. I. Their relationship to paroxysmal nocturnal hemoglobinuria. Blood 1961, 17, 83.

16. Dacie, J. V., S. M. Lewis, and D. Tills. Comparative sensitivity of the erythrocytes in paroxysmal nocturnal haemoglobinuria to haemolysis by acidified normal serum and by high-titre cold antibody. Brit. J. Haemat. 1960, 6, 362.

17. Rosse, W. F., and J. V. Dacie. Immune lysis of normal human and paroxysmal nocturnal hemoglobinuria (PNH) red cells. II. The role of complement components in the increased sensitivity of $\mathrm{PNH}$ red cells to immune lysis. J. clin. Invest. 1966, 45, 749.

18. Levy, L. R., and I. H. Lepow. Assay and properties of serum inhibitor of C'1-esterase. Proc. Soc. exp. Biol. (N. Y.) 1959, 101, 608.

19. Andre, R., B. Dreyfus, D. Vergoz, and A. Najman. Remarques sur un cas de maladie de MarchiafavaMicheli, évoluant longtemps sous l'aspect d'une pancytopénie chronique. Presse méd. 1963, 71, 610.

20. Quagliana, J. M., G. E. Cartwright, and M. M. Wintrobe. Paroxysmal nocturnal hemoglobinuria following drug-induced aplastic anemia. Ann. intern. Med. 1964, 61, 1045.

21. Crosby, W. H. Paroxysmal nocturnal hemoglobinuria. Relation of the clinical manifestations to underlying pathogenic mechanisms. Blood 1953, 8, 769.

22. Dacie, J. V. Paroxysmal nocturnal hæmoglobinuria. Proc. roy. Soc. Med. 1963, 56, 587.

23. Dacie, J. V., and P. L. Mollison. Survival of transfused erythrocytes from a donor with nocturnal hæmoglobinuria. Lancet 1949, 1, 390.

24. Lewis, S. M., L. Szur, and J. V. Dacie. The pattern 
of erythrocyte destruction in haemolytic anaemia, as studied with radioactive chromium. Brit. J. Haemat. 1960, 6, 122.

25. Kan, S. Y., and F. H. Gardner. Life span of reticulocytes in paroxysmal nocturnal hemoglobinuria. Blood 1965, 25, 759.

26. Rosse, W. F. The life span of the two populations of red cells in paroxysmal nocturnal hemoglobinuria determined by cohort labelling. In preparation.

27. Crosby, W. H. Paroxysmal nocturnal hemoglobinuria. Plasma factors in the hemolytic system. Blood 1953, 8, 444.
28. Yachnin, S., and J. M. Ruthenberg. The initiation and enhancement of human red cell lysis by activators of the first component of complement and by first component esterase: studies using normal red cells and red cells from patients with paroxysmal nocturnal hemoglobinuria. J. clin. Invest. 1965, 44, 518.

29. Rosse, W. F., R. Dourmashkin, and J. R. Humphrey, Immune lysis of normal human and paroxysmal nocturnal hemoglobinuria (PNH) red blood cells. III. The membrane defects caused by complement. J. exp. Med. In press. 